\title{
老年泌尿器科手術患者の臨床統計
}

\begin{tabular}{|c|c|c|c|}
\hline & 阿 & 岸 & 鉄 \\
\hline & 高 & 橋 & 靖 \\
\hline & 彦 & 坂 & 幸 \\
\hline & 片 & 岡 & 頌 \\
\hline & 大 & 野 三 & 太 \\
\hline $\begin{array}{c}\text { 神戸大学医学部泌尿器科教室 } \\
\text { (任:石神釷次教授) }\end{array}$ & 三 & 田 & 俊 \\
\hline & 寺 & 杣 & 一 \\
\hline & 田 & 中 & 邦 \\
\hline & 広 & 岡九 & 兵 \\
\hline & 守 & 殿 & 貞 \\
\hline & 石 & 神 & 襄 \\
\hline
\end{tabular}

\section{STATISTICS OF GERIATRIC UROLOGY}

Tetsuzo Agishi, Yasumasa Takahashi, Koji Hikosaka, Nobuo Kataoka

Santaro Oono, Toshihiko Mita, Kazunori Terasoma,

Kunihiko Tanaka, Kyubei Hirooka,

Sadao Kamidono, Joji Ishigami

Department of Urology Kobe University School of Medicine

(Director: Professor Joji Ishigami)

The clinical observations were made on the aged patients over 60 years old admitted in Department of Urology, Kobe University during the period of 1967 to 1971.

Aged patients over 60 years old occupied about one third of all in-patients, and about one third of them were admitted for treatment of benign prostate hypertrophy.

Abnormality rates in the examination findings increased with age, and became more marked after operation.

On admission, there were no special differences in the abnormality rates between postoperative death cases and alive-discharged cases, while general findings of non-operative death cases were significantly impaired. In prostatectomy, massive bleeding during operation delayed the discharge from hospital. In nephrectomy, aged patients suffered more disturbances in physical condition than in other urologic surgery, and on the other hand, prime patients suffered less.

はじめに

新しい医学知識・技術の開発によつて，かつては危険 視されていたよらな小児・老年者の手術的治療も安全に 行なわれるよらになつてきている，小児泌尿器科は，現 在ではある程度, 明確に独立した領域をもち，そこでは 小児は特別な代謝機構をるつものとして取り扱われてい
る.

他方，老年者では，術後の異常な経過などについての 特殊性は認識されてはいるが，小児泌尿器科に拈けるよ らな明確な独立性はないよらである。

泌尿器科においては, 特に老年男性を治療の対象とし て取り扱らことが多く，その臨床統計を検討し，問題点 
を探ることは有意義と考兄れる。

そこで，われわれは神戸大学医学部泌尿器科教室にお。 いて, 過去 5 年間に手術を前提として入院した患者で, 60才以上の者を対象とし，

1）泌尿器科領域で取り扱つている老年患者数，それ ら老年患者の疾患, 手術の分類, 頻度などの総論的事項

2）入院時の一般身体所見

3）術後の身体反応など

について臨床統計的観察を行ない，同時に，同期間に㧊 ける40〜55才の壮年患者を対象群として, 老年者との身 体所見に差が認められるかを検討した。これらは，老年 手術患者の術前・術後管理での問題点を明らかとするこ とを目的としているのである.

\section{総論的事項}

II-1 入院患者年度別及び年令別数

（表 1）の如く，5 年間の 60 才以上の患者総数は， 588名である．各年度別には，極くわずかずつではある が増加の傾向があるようである。しかし, 全入院患者に 対する比率からい学ば，余り変動がなく，約 $1 / 3$ が老年患 者で占められていることが判る．5才毎に分けてみる と，60〜64才，65〜69才，70〜74才では，各年令区分毎 に差はなく全体の約 $1 / 4$ づつ，75〜79才は, 更にその約半 数, 80 才以上が更に大凡その半数といら分布になつてい る.

男女比では, 女性生殖器の疾患が婦人科で治療される ことのため，圧倒的に男性が多い。しかも，年令が進む

表 1 老年入院患者年度別及び年令別数

\begin{tabular}{|c|c|c|c|c|c|c|c|c|c|c|}
\hline \multicolumn{2}{|c|}{$\begin{array}{lll} & \text { 年 } \text { 度 } \\
\text { 年 } & \text { 令 } & \\
\end{array}$} & 1967 & 1968 & 1969 & 1970 & 1971 & 小計 & 男/女 & 計 & $\%^{11}$ \\
\hline \multirow{2}{*}{$60 \sim$} & $\hat{0}$ & 25 & 22 & 22 & 24 & 24 & 117 & \multirow{2}{*}{$3.3 / 1$} & \multirow{2}{*}{152} & \multirow{2}{*}{25.9} \\
\hline & 우 & 5 & 6 & 8 & 8 & 8 & 35 & & & \\
\hline \multirow{2}{*}{$65 \sim$} & $\hat{0}$ & 18 & 28 & 26 & 29 & 33 & 134 & \multirow{2}{*}{$5.4 / 1$} & \multirow{2}{*}{159} & \multirow{2}{*}{27.0} \\
\hline & 우 & 6 & 2 & 5 & 6 & 6 & 25 & & & \\
\hline \multirow{2}{*}{$70 \sim$} & $\hat{\delta}$ & 24 & 29 & 31 & 32 & 23 & 139 & \multirow{2}{*}{$7.3 / 1$} & \multirow{2}{*}{158} & \multirow{2}{*}{26.9} \\
\hline & 우 & 2 & 4 & 5 & 3 & 5 & 19 & & & \\
\hline \multirow{2}{*}{$75 \sim$} & $\hat{0}$ & 18 & 13 & 16 & 12 & 15 & 74 & \multirow{2}{*}{$14.8 / 1$} & \multirow{2}{*}{79} & \multirow{2}{*}{13.4} \\
\hline & 우 & & 1 & 1 & 2 & 1 & 5 & & & \\
\hline \multirow{2}{*}{$80 \sim$} & $\hat{0}$ & 9 & 5 & 3 & 10 & 11 & 38 & \multirow{2}{*}{$19.0 / 1$} & \multirow{2}{*}{40} & \multirow{2}{*}{6.8} \\
\hline & 우 & & & & 1 & 1 & 2 & & & \\
\hline 計 & & 107 & 110 & 117 & 127 & 127 & & & 588 & \\
\hline$\%^{2)}$ & & 35.8 & 33.8 & 32.5 & 35.7 . & 35.2 & & & & \\
\hline
\end{tabular}

（1）全老年入院患者に対する\%

令 : 우 $=5.8: 1$

（2）全入院患者に対する\%

表 2 疾患別分類

\begin{tabular}{|c|c|c|c|c|c|c|c|c|c|c|c|c|c|c|c|c|c|}
\hline 疾 患 & 結膀 & & & 新 & 生 & 生 & 生 & & & & 性 & 器 & 太の & 疾 患 & & z & \\
\hline 年 令 & $\mid \begin{array}{l}\text { 核胱 } \\
\text { 腎な } \\
\text { •ど }\end{array}$ & $\begin{array}{l}\text { 前 } \\
\text { 立 } \\
\text { 腺 }\end{array}$ & $\begin{array}{l}\text { 鼻 } \\
\text { 丸 }\end{array}$ & $\begin{array}{l}\text { 院 } \\
\text { 茎 }\end{array}$ & $\begin{array}{l}\text { 膀 } \\
\text { 胱 }\end{array}$ & 腎 & $\begin{array}{l}\text { 腎 } \\
\text { 衄 }\end{array}$ & $\begin{array}{l}\text { 尿 } \\
\text { 管 }\end{array}$ & $\begin{array}{l}\text { そ } \\
\text { の } \\
\text { 他 }\end{array}$ & 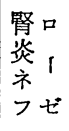 & $\begin{array}{l}\text { 腎 } \\
\text { の } \\
\text { 感 } \\
\text { 染 }\end{array}$ & $\begin{array}{l}\text { 泌の } \\
\text { 尿結 } \\
\text { 器石 }\end{array}$ & $\begin{array}{l}\text { 层 } \\
\text { 道 } \\
\text { 荻 } \\
\text { 窄 }\end{array}$ & $\begin{array}{l}\text { 前肥 } \\
\text { 立大 } \\
\text { 腺症 }\end{array}$ & $\begin{array}{l}\text { そ } \\
\text { の } \\
\text { 他 }\end{array}$ & $\begin{array}{l}\text { の } \\
\text { 他 }\end{array}$ & 計 \\
\hline $60 \sim$ & & 8 & 2 & 2 & 38 & 7 & & 1 & 2 & 1 & & 19 & 6 & 43 & 22 & 1 & 152 \\
\hline $65 \sim$ & 2 & 6 & 1 & 4 & 37 & 2 & 1 & 1 & 2 & 1 & & 18 & 2 & 59 & 22 & 1 & 159 \\
\hline $70 \sim$ & & 17 & & & 44 & 5 & & 1 & 3 & & 2 & 15 & 1 & 57 & 17 & 4 & 166 \\
\hline $75 \sim$ & 2 & 10 & 1 & & 14 & & & 1 & 2 & & & 8 & 1 & 35 & 7 & 1 & 82 \\
\hline $80 \sim$ & & 8 & & & 8 & 1 & & & & 1 & & 2 & 1 & 16 & 2 & 1 & 40 \\
\hline 計 & 4 & 49 & 4 & 6 & 141 & 15 & 1 & 4 & 9 & 3 & 2 & 62 & 11 & 210 & 70 & 8 & 599 \\
\hline $\begin{array}{l}\text { 全疾患に } \\
\text { 対 }\end{array}$ & 0.7 & 8.2 & 0.7 & 1.0 & 23.6 & 2.5 & 0.2 & 0.7 & 1.5 & 0.5 & 0.3 & 10.0 & 1.8 & 35.1 & 11.7 & 1.3 & \\
\hline
\end{tabular}


表 3 手術術式

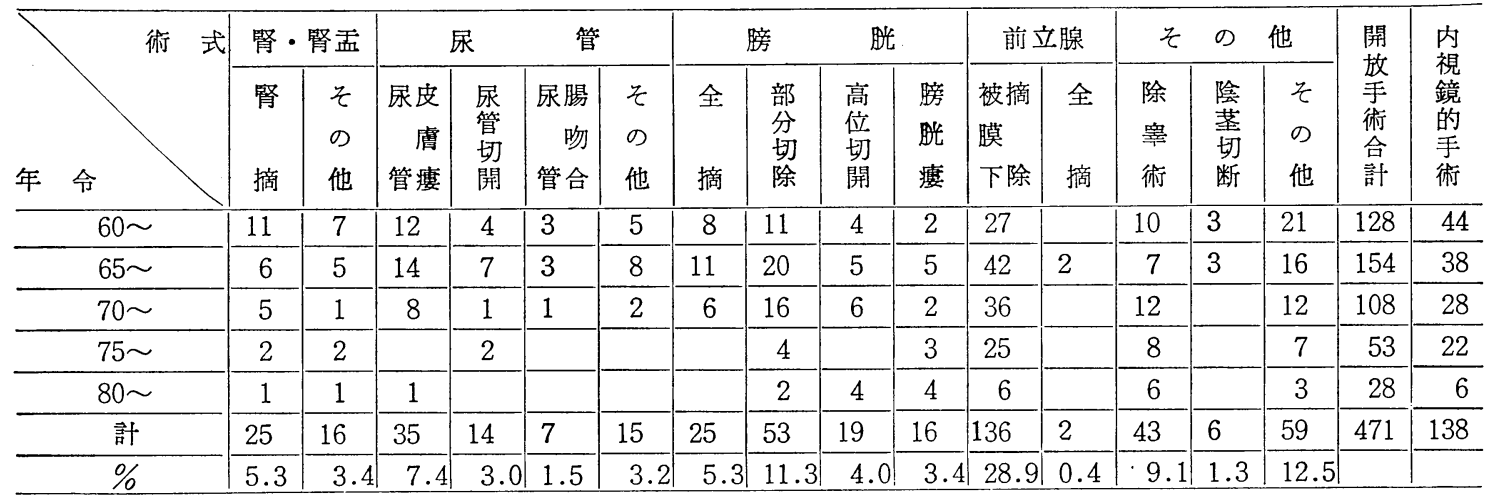

そつれて，その差は大となる。これは，女性の平均寿命 が男性より長いということと考光わせてみると奇異に 思えるが，その原因は不明である. 全男性：全女性=

\section{$5.8 ： 1$ である.}

\section{II-2 疾患別分類}

厚生省編の疾病分類 ${ }^{1}$ 飞従うと（表 2）の如くであ る. 同一患者で 2 つ以上の疾患を有する場合, 各 1 つづ つを記載しているため疾患数は患者数よりも多くなつて いる.

前立腺肥大症の患者が最も多くて $35.1 \%$ ，次いで膀脱 新生物 $23.6 \%$, 泌尿器の結石 $10.0 \%$ な゙である。この 3 つの疾患で全体の約 $70 \%$ 占める. 老年泌尿器科患者の $1 / 3$ 以上が，前立腺肥大症の治療のため入院してくるので ある。

\section{II -3 手術術式}

同一患者に 2 つ以上の手術が施行された場合には，各 々の手術が別々に記載されている。

（表3）に見られるように，観血的開放手術では，や
はり前立腺被膜下摘除術が最も多く, $28.9 \%$, 次いで多 いのは膀脂新生物に対する膀脂部分切除術の $11.3 \%$ であ る.

\section{入院時（術前）及び術後検查所見}

入院時 (術前) 及び術後の種々の検査所見を, 60才以 上の老年者と 40～55才の壮年者群とで比較した.

III -1 術前肺活量（表 4 ）

老年者では，最大分布を占めるのは $2500 ３ 000 \mathrm{ml}$ の もの, 壮年者昼は $3500 \mathrm{ml}$ 以上のものであり, 壮年者で の肺活量は明らかに多く，老年者での肺活量減少傾向は 加令と関係が深い。

III -2 術前赤血球数（表 5 ）

老年者は，350万〜 450 万 $/ \mathrm{mm}^{3}$ のものが約 $65 \%$, 壮 年者では $400 \sim 500$ 万 $/ \mathrm{mm}^{3}$ のものが約 $60 \%$ であつて， 老年者の貧血傾向は明らかである，乙かし，貧血傾向は 加令と共に強くなるとはい方ない。

III -3 術前最大血圧（表 6 )

老年者での最大分布を占めるのは $160 \mathrm{~mm} \mathrm{Hg}$ 以上のもの

表 4 肺 活 量

\begin{tabular}{c|c|c|c|c|c|c|c}
\hline 年 令 & $1500 \mathrm{ml}>$ & $\geqq 1500$ & $\geqq 2000$ & $\geqq 2500$ & $\geqq 3000$ & $\geqq 3500$ & 計 \\
\hline $60 \sim$ & 5 & 18 & 18 & 20 & 31 & 12 & 104 \\
\hline $65 \sim$ & 7 & 14 & 26 & 33 & 33 & 19 & 132 \\
\hline $70 \sim$ & 10 & 11 & 21 & 35 & 19 & 10 & 106 \\
\hline $75 \sim$ & 3 & 8 & 18 & 15 & 6 & 7 & 57 \\
\hline $80 \sim$ & 2 & 6 & 6 & 3 & 4 & 3 & 24 \\
\hline 計 & 27 & 57 & 89 & 106 & 93 & 51 & 423 \\
\hline$\%$ 分布 & 6.4 & 13.5 & 21.0 & 25.1 & 22.0 & 12.1 & \\
\hline $40 \sim 55$ & 3 & 23 & 52 & 53 & 45 & 70 & 246 \\
\hline$\%$ 分布 & 1.2 & 9.3 & 21.1 & 21.5 & 18.3 & 28.5 & \\
\hline
\end{tabular}


表 5 赤血 球数

\begin{tabular}{|c|c|c|c|c|c|c|c|}
\hline $\begin{array}{ll}\text { 年 } & \text { 命 } \\
\end{array}$ & $\geqq 500$ 万 $/ \mathrm{mm}^{3}$ & $\geqq 450$ 万 & $\geqq 400$ 万 & $\geqq 350$ 万 & $\geqq 300$ 万 & 300 万> & 計 \\
\hline $60 \sim$ & 7 & 28 & 48 & 37 & 7 & 8 & 135 \\
\hline $65 \sim$ & 13 & 31 & 47 & 51 & 12 & 5 & 159 \\
\hline $70 \sim$ & 5 & 20 & 50 & 39 & 9 & 12 & 135 \\
\hline $75 \sim$ & 2 & 12 & 24 & 27 & 5 & 3 & 73 \\
\hline $80 \sim$ & 1 & 1 & 11 & 14 & 9 & 1 & 37 \\
\hline 計 & 28 & 92 & 180 & 168 & 42 & 29 & 539 \\
\hline \%分布 & 5.2 & 17.1 & 33.4 & 31.2 & 7.8 & 5.4 & \\
\hline $40 \sim 55$ & 39 & 82 & 88 & 52 & 19 & 12 & 292 \\
\hline$\%$ 分布 & 13.4 & 28.1 & 30.1 & 17.8 & 6.5 & 4.1 & \\
\hline
\end{tabular}

表 6 血圧

\begin{tabular}{|c|c|c|c|c|c|c|c|c|c|}
\hline 年 令 & $\geqq 160 \mathrm{~mm} H g$ & $\geqq 150$ & $\geqq 140$ & $\geqq 130$ & $\geqq 120$ & $\geqq 110$ & $\geqq 100$ & $100>$ & 計 \\
\hline $60 \sim$ & 23 & 26 & 23 & 23 & 19 & 15 & 5 & 1 & 135 \\
\hline $65 \sim$ & 38 & 32 & 16 & 30 & 13 & 9 & 8 & & 146 \\
\hline $70 \sim$ & 40 & 26 & 14 & 21 & 11 & 6 & 3 & 3 & 124 \\
\hline $75 \sim$ & 22 & 17 & 10 & 8 & 8 & 2 & 1 & & 68 \\
\hline $80 \sim$ & 17 & 4 & 5 & 4 & & 3 & & 1 & 34 \\
\hline 計 & 140 & 105 & 68 & 86 & 51 & 35 & 17 & 5 & 507 \\
\hline \%分布 & 27.6 & 20.7 & 13.4 & 17.0 & 10.1 & 6.9 & 3.4 & 1.0 & \\
\hline $40 \sim 55$ & 30 & 27 & 40 & 41 & 65 & 39 & 21 & 16 & 279 \\
\hline \%分布 & 10.8 & 9.7 & 14.3 & 14.7 & 23.3 & 14.0 & 7.5 & 5.7 & \\
\hline
\end{tabular}

表 7 心電図異常

\begin{tabular}{c|c|c|c|c|c}
\hline 年令 & $(-)$ & $(+)$ & $(\mathrm{H})$ & $(\mathrm{HI})$ & 計 \\
\hline $60 \sim$ & $\begin{array}{c}84 \\
(65.1 \%)\end{array}$ & 32 & 12 & 1 & 129 \\
\hline $65 \sim$ & $\begin{array}{c}92 \\
(61.7 \%)\end{array}$ & 35 & 21 & 1 & 149 \\
\hline $70 \sim$ & $\begin{array}{c}63 \\
(47.0 \%)\end{array}$ & 40 & 29 & 2 & 134 \\
\hline $75 \sim$ & $\begin{array}{c}36 \\
36\end{array}$ & 16 & 15 & 1 & 68 \\
\hline $80 \sim$ & $\begin{array}{c}(52.9 \% \\
15\end{array}$ & 10 & 7 & 4 & 36 \\
\hline 計 & $\frac{(41.7 \%)}{290}$ & 133 & 84 & 9 & 516 \\
\hline$\%$ 分布 & 56.2 & 25.8 & 16.3 & 1.7 & \\
\hline $40 \sim 55$ & 208 & 44 & 8 & 3 & 263 \\
\hline$\%$ 分布 & 79.1 & 16.7 & 3.0 & 1.1 & \\
\hline
\end{tabular}

であり, 壮年者では $120 \mathrm{~mm} \mathrm{Hg}$ 台のものである. 老年者で の高血圧の傾向が明白である.

III -4 術前心電図異常（表 7 )

期外収縮・左室肥大のみのものを $(+)$, 軽度の心筋障
表 8 P S P

\begin{tabular}{c|c|c|c|c}
\hline 年 令 & $\geqq 25 \%$ & $55>$ & $30>$ & 計 \\
\hline $60 \sim$ & $\begin{array}{c}87 \\
(75.7 \%)\end{array}$ & 24 & 4 & 115 \\
\hline $65 \sim$ & $\begin{array}{c}87 \\
(67.9 \%)\end{array}$ & 31 & 10 & 128 \\
\hline $70 \sim$ & $\begin{array}{c}80 \\
(62.9 \%)\end{array}$ & 35 & 12 & 127 \\
\hline $75 \sim$ & $\begin{array}{c}40 \\
(64.5 \%)\end{array}$ & 20 & 2 & 62 \\
\hline $80 \sim$ & $\begin{array}{c}14 \\
(48.3 \%)\end{array}$ & 14 & 1 & 29 \\
\hline 計 & 308 & 124 & 29 & 461 \\
\hline$\%$ 分布 & 66.8 & 26.9 & 6.3 & \\
\hline $40 \sim 55$ & 187 & 49 & 19 & 255 \\
\hline$\%$ 分布 & 73.3 & 19.2 & 7.5 & \\
\hline
\end{tabular}

害・冠不全・脚ブロックが単独に存在するものを(H), それ以上の異常を（州）と分類してみると，何らかの異 常を認めたものは，老年者では $43.8 \%$ と驚くべき高率を 示すに対して壮年者では約 $20 \%$ である. 又, 異常を示す 
表 9 B U N

\begin{tabular}{|c|c|c|c|c|c|}
\hline 年令 & $20 \mathrm{mg} / \mathrm{dl}>$ & $\geqq 20$ & $\geqq 50$ & $\geqq 100$ & 計 \\
\hline $60 \sim$ & $\mid \begin{array}{c}104 \\
(68.4 \%)\end{array}$ & 43 & 5 & & 152 \\
\hline $65 \sim$ & $\begin{array}{c}98 \\
(61.7 \%)\end{array}$ & 50 & 11 & & 159 \\
\hline $70 \sim$ & $\begin{array}{c}98 \\
(62.0 \%) \\
\end{array}$ & 54 & 6 & & 158 \\
\hline $75 \sim$ & $\begin{array}{c}50 \\
(63.3 \%) \\
\end{array}$ & 24 & 4 & 1 & 79 \\
\hline $80 \sim$ & $\begin{array}{c}22 \\
(55.0 \%) \\
\end{array}$ & 14 & 4 & & 40 \\
\hline 計 & 372 & 185 & 30 & 1 & 588 \\
\hline \%分布 & 63.3 & 31.5 & 5.0 & 0.2 & \\
\hline $40 \sim 55$ & 236 & 88 & 10 & 2 & 336 \\
\hline \%分布 & 70.2 & 26.2 & 3.0 & 0.6 & \\
\hline
\end{tabular}

表10 血清蛋白量

\begin{tabular}{|c|c|c|c|c|}
\hline 年 令 & $\geqq 6.5 \mathrm{~g} / \mathrm{dl}$ & $\geqq 6.0$ & $6.0>$ & 計 \\
\hline $60 \sim$ & $\begin{array}{c}112 \\
(84.2 \%) \\
\end{array}$ & 19 & 2 & 133 \\
\hline $65 \sim$ & $\begin{array}{c}115 \\
(81.0 \%)\end{array}$ & 19 & 8 & 142 \\
\hline $70 \sim$ & $\begin{array}{c}106 \\
(83.4 \%) \\
\end{array}$ & 17 & 4 & 127 \\
\hline $75 \sim$ & $\begin{array}{c}51 \\
(73.8 \%) \\
\end{array}$ & 13 & 5 & 69 \\
\hline $80 \sim$ & $\begin{array}{c}23 \\
(67.7 \%) \\
\end{array}$ & 8 & 3 & 34 \\
\hline 計 & 407 & 76 & 22 & 505 \\
\hline \%分布 & 80.6 & 15.0 & 4.4 & \\
\hline $40 \sim 55$ & 236 & 27 & 7 & 270 \\
\hline \%分布 & 87.4 & 10.0 & 2.6 & \\
\hline
\end{tabular}

率は年令と共に高くなる傾向にあるといえる。

III-5 術前 PSP 及び BUN（表 8 及び表 9)

PSP 值では，15分值で25\%以上であれば正常と認め， 更に異常と認めたものを 120 分值で55\%以下のものと， 更に $30 \%$ 以下のものとに分けて検討した．正常と認めら れたのは老年者では66.8\%，壮年者では73.3\%であつ た. 老年者では, 加令と共に正常值を示すものが少なく なる傾向がうかがえた。

BUN 值では, 20mg/dl以下を正常とし, 異常値を示す ものを更に $50 \mathrm{mg} / \mathrm{dl}$ 以上と, $100 \mathrm{mg} / \mathrm{dl}$ 以上のものとに分け た. 老年者の方が壮年者に比して, 正常值を示するのが 少ないが，加令との関係は不明である.

III-6 術前血清蛋白 (T.P.) 及び BSP（表10及び 表11)
表11 B S P

\begin{tabular}{c|c|c|c|c}
\hline 年 令 & $5 \% \geqq$ & $>5$ & $>10$ & 計 \\
\hline $60 \sim$ & $\begin{array}{c}75 \\
(85.5 \%)\end{array}$ & 8 & 4 & 84 \\
\hline $65 \sim$ & $\begin{array}{c}80 \\
(77.7 \%)\end{array}$ & 16 & 7 & 103 \\
\hline $70 \sim$ & $\begin{array}{c}70 \\
(77.8 \%)\end{array}$ & 11 & 9 & 90 \\
\hline $75 \sim$ & $\begin{array}{c}47 \\
(87.0 \%)\end{array}$ & 3 & 4 & 54 \\
\hline $80 \sim$ & $\begin{array}{c}21 \\
(85.0 \%)\end{array}$ & 5 & 2 & 28 \\
\hline 計 & 293 & 43 & 26 & 362 \\
\hline$\%$ 分布 & 80.9 & 11.9 & 7.2 & \\
\hline $40 \sim 55$ & 164 & 11 & 11 & 186 \\
\hline$\%$ 分布 & 88.2 & 5.9 & 5.9 & \\
\hline
\end{tabular}

$6.5 \mathrm{~g} / \mathrm{dl}$ 以上の血清蛋白量を示したものは, 老年者で は壮年者に比して明らかに少ない，又，加令と共に少な くなる傾向を示すよらである。

BSP 值では，30分值で $5 \%$ 以下を正常值と認めると， 正常值を示したものは，老年者では壮年者に比して明ら かに少ない。しかし加令とは明らかな関係はない。

以上, 入院時 (術前) の肺活量 $\cdot$ 赤血球数 $\cdot$ 最大血 圧・心電図・PSP 及び BUN ・ 血清蛋白量及び BSP に ついて述べたが，これらは術後の検査所見も術前とは著 明な差異は認められなかつた。 しかし, 以下に述べるも のは，注意深い術後管理にも拘らず術後検査所見に明ら かな変化を認めたものである。

III-7 術前・術後の血清 $\mathrm{Na}^{+}$及び血清 $\mathrm{K}^{+}$(図 1)

$148 \mathrm{mEq} / \mathrm{L} \geqq \mathrm{S}-\mathrm{Na}^{+} \geqq 136 \mathrm{mEq} / \mathrm{L} \quad$ 及び $4.8 \mathrm{mEq} / \mathrm{L} \geqq$ $\mathrm{S}-\mathrm{K}^{+} \geqq 3.6 \mathrm{mEq} / \mathrm{L}$ を正常值と認めると, 正常值を示 すものは, $\mathrm{S}-\mathrm{Na}^{+}$でも, $\mathrm{S}-\mathrm{K}^{+}$でも老年者は壮年者に

図 1
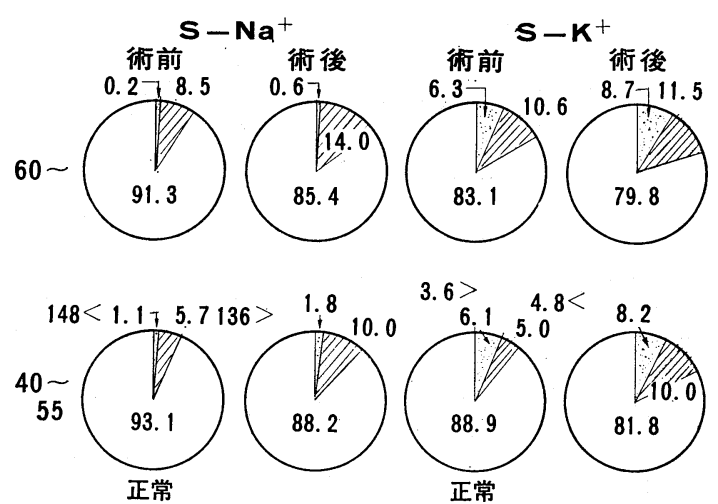
図 2
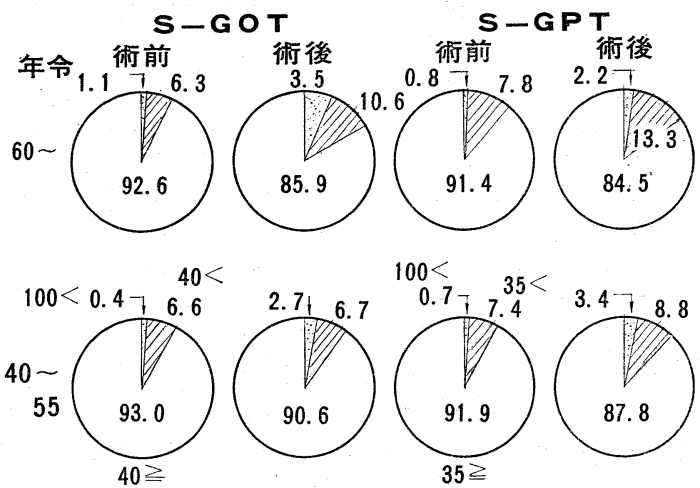

比して少ない，又，老年者でも，壮年者でも術後は術前 に比して正常值を示するのが少なくなる。

ただ， $\mathrm{S}-\mathrm{Na}^{+}$では術後，低血症となる傾向があるの に対して，S-K+ では高血症の傾向となる差違があ る.

III-8 術前・術後の S-GOT 及び S-GPT (図 2)

S-GOT では40K.U. 以上, S-GPT では35K.U. 以上 を異常值と認めると, 両者共老年者は, 壮年者に比して 異常值を示するのが多く，又，術前に比して術後には異 常值を示すものが明らかに多くなる。

\section{術術合併症及び死亡例}

\section{IV-1 術後合併症（表12）}

術後合併症として最も高率に生ずるのは, 膀脂炎・腎 盂炎などの尿路感染で, 前立腺摘除術後などの殆んぞ必 発する膀胱炎なども含めているため，40\%以上の高発生 率となつている。

創傷治癒遅延・尿瘦などについては，一般に低蛋白血 症との密接な関連のあることがいわれている. 先述の如 く，血清蛋白量は加令と共に低下する傾向を認めたが，

表12 術後合併症発生率\%

\begin{tabular}{|c|c|c|c|c|c|c|}
\hline 年令 & $\begin{array}{l}\text { 創治癒 } \\
\text { 遅 延 }\end{array}$ & 尿瘻* & $\begin{array}{l}\text { 尿路 } \\
\text { 感染 }\end{array}$ & $\begin{array}{l}\text { 肺 合 } \\
\text { 併症* }\end{array}$ & $\begin{array}{l}\text { 消化器 } \\
\text { 出 血** }\end{array}$ & $\begin{array}{l}\text { 腸 管 } \\
\text { 麻痺* }\end{array}$ \\
\hline $60 \sim$ & 12.8 & 7.8 & 41.7 & 3.1 & 0.8 & 2.3 \\
\hline $65 \sim$ & 8.3 & 5.2 & 48.4 & 5.2 & 2.6 & 2.6 \\
\hline $70 \sim$ & 8.6 & 6.5 & 55.9 & 5.5 & 1.9 & 5.6 \\
\hline $75 \sim$ & 12.0 & 5.7 & 54.7 & 7.5 & 1.9 & 1.9 \\
\hline $80 \sim$ & 5.9 & 7.1 & 50.0 & 14.3 & 0 & 0 \\
\hline
\end{tabular}

* 観血的手術例に対する比率
創傷治癒遅延及び㽷瘦発生については，加令との関係は 認められない。

肺合併症の発生については，明らかな加令との相関を 認める。しかしながら，一般腹部外科で，老年者術後 合併症として最高率に生ずる程に高率に生ずるのではな い，その差異の生ずる原因としては，泌尿器科手術は腹 膜外で，しかも比較的下腹部での操作が多く，これらが 何らかの意味をもつものと考兄られる．先述の如く，肺 活量は加令と共に著明に減少するものであり，術前から の深呼吸訓練・術後早期起坐などの肺換気を活溌にする 努力が医療を施す側に必要であると考えられる。

その他, 消化器出血・腸管麻痺などあるが，加令との 明らかな関係は認められない。

IV-2 死亡例

入院するときは，原則的には手術することを前提とし ているのであるが，手術せずに死亡した例が 5 年間に 10 例ある（表13）.この非手術死亡例では，加令との関係は 認められない. 又，手術後 1 カ月以内に入院中死亡した 表13 死亡例の内訳

\begin{tabular}{|c|c|c|c|c|c|}
\hline \multirow[b]{2}{*}{ 年令 } & \multicolumn{2}{|c|}{ 手術死亡例 } & \multirow{2}{*}{$\begin{array}{l}\text { 非手術 } \\
\text { 死亡例 } \\
\\
\text { 病死 }\end{array}$} & \multicolumn{2}{|c|}{ 計 } \\
\hline & $\begin{array}{c}\text { 手術死 } \\
\left(\begin{array}{cc}\text { 術後 } 1 \\
\text { 力月内 }\end{array}\right)\end{array}$ & $\left(\begin{array}{cc}\text { 手術後 } \\
\text { 病 } & \text { 死 } \\
\text { 術 } & \text { 後 } \\
1 & \text { 力 } \\
\text { 以 } & \text { 後 }\end{array}\right)$ & & 数 & $\begin{array}{l}\text { 全患者 } \\
\text { に対す } \\
\text { る } \%\end{array}$ \\
\hline $60 \sim$ & 6 & 2 & 1 & 9 & 5.9 \\
\hline $65 \sim$ & 1 & 1 & 1 & 3 & 1.9 \\
\hline $70 \sim$ & 5 & 2 & 4 & 11 & 7.0 \\
\hline $75 \sim$ & & & 2 & 2 & 2.5 \\
\hline $80 \sim$ & 1 & & 2 & 3 & 7.5 \\
\hline 計 & 13 & 5 & 10 & 28 & 4.7 \\
\hline $40 \sim 55$ & 5 & 5 & 1 & 11 & 3.2 \\
\hline
\end{tabular}

ものを手術死とし，1 カ月以上経てから死亡したものを 手術後病死として分類し，検討してみても，死亡率と加 令とは関係がない．壮年者と比較してみても，特に死亡 率が高いというのでもない.

各手術術式別にみても加令との関係は認められない (表14).前立腺摘除術 136例中の手術死亡は 2 例（1.5 \%)で，比較的安全な手術といえる.これに対して，膀 脱全摘は 25 例中 7 例 $(28.0 \%)$ の死亡を及，手術適応の 撰択，術後管理などの点に反省すべきものがあつたと考 えている。

全観血的開放手術（471例）に対する術後死亡は17例 ( $3.7 \%)$ で，手術適応の問題もあろうが，他の報告文 
表 14 手術死亡例

\begin{tabular}{|c|c|c|c|c|c|c|c|c|}
\hline \multirow{2}{*}{ 年 令 } & \multirow{2}{*}{$\begin{array}{l}\text { 前立腺 } \\
\text { 摘除術 }\end{array}$} & \multirow{2}{*}{$\begin{array}{l}\text { 膀脱 } \\
\text { 全摘 }\end{array}$} & \multirow{2}{*}{$\begin{array}{l}\text { 膀胱部 } \\
\text { 分切除 }\end{array}$} & \multirow{2}{*}{$\begin{array}{l}\text { 腎瘻, 尿 } \\
\text { 管皮虐瘻 }\end{array}$} & \multirow{2}{*}{ 腎摘 } & \multirow[b]{2}{*}{ その他 } & \multicolumn{2}{|c|}{ 計 } \\
\hline & & & & & & & 数 & $\begin{array}{l}\text { 全患者に } \\
\text { 対する\% }\end{array}$ \\
\hline $60 \sim$ & & 4 & 2 & 2 & & & 8 & 5.2 \\
\hline $65 \sim$ & & 1 & & 1 & & & 2 & 1.3 \\
\hline $70 \sim$ & 2 & 2 & 1 & 1 & 1 & & 7 & 4.4 \\
\hline $75 \sim$ & & & & & & & 0 & 0 \\
\hline $80 \sim$ & & & & & & 1 & 1 & 2.5 \\
\hline $\begin{array}{c}\text { 計 } \\
\text { (全手術数) }\end{array}$ & $\begin{array}{c}2 \\
(136)\end{array}$ & $\begin{array}{c}7 \\
(25) \\
\end{array}$ & $\begin{array}{c}3 \\
(53) \\
\end{array}$ & $\begin{array}{c}4 \\
(35) \\
\end{array}$ & $\begin{array}{c}1 \\
(25) \\
\end{array}$ & $\begin{array}{c}1 \\
(59)\end{array}$ & $\begin{array}{c}18 \\
(609) \\
\end{array}$ & 3.0 \\
\hline $40 \sim 55$ & & 3 & 1 & 3 & & 3 & 10 & 3.0 \\
\hline
\end{tabular}

表15 死亡例の入院時所見（I）

\begin{tabular}{|c|c|c|c|c|c|c|c|c|c|}
\hline 血 圧 & $\geqq \underset{\mathrm{mm} H g}{160}$ & $\geqq 150$ & $\geqq 140$ & $\geqq 130$ & $\geqq 120$ & $\geqq 110$ & $\geqq 100$ & $100>$ & 例数 \\
\hline $\begin{array}{c}\text { 手術後死亡 } \\
\text { (\%分布) }\end{array}$ & $\begin{array}{c}5 \\
(33.3)\end{array}$ & $(6.7)$ & $\begin{array}{c}5 \\
(33.3)\end{array}$ & $\begin{array}{c}2 \\
(13.3)\end{array}$ & $\begin{array}{l}1 \\
(6.7)\end{array}$ & & $\begin{array}{l}1 \\
(6.7)\end{array}$ & & 15 \\
\hline $\begin{array}{c}\text { 非手術死亡 } \\
(\% \text { 分布) }\end{array}$ & $\begin{array}{c}3 \\
(75.0)\end{array}$ & & & & & & & $\begin{array}{c}1 \\
(25.0)\end{array}$ & 4 \\
\hline $\begin{array}{l}\text { 全患者での } \\
\% \text { 分 布 }\end{array}$ & 27.6 & 20.7 & 13.4 & 17.0 & 10.1 & 6.9 & 3.4 & 1.0 & \\
\hline
\end{tabular}

\begin{tabular}{|c|c|c|c|c|c|}
\hline 心 電 図 & $(-)$ & $(+)$ & (H) & (H) & 例 数 \\
\hline $\begin{array}{l}\text { 手術後死亡 } \\
\text { (\%分布) }\end{array}$ & $\begin{array}{c}6 \\
(40.0)\end{array}$ & $\begin{array}{c}4 \\
(26.7)\end{array}$ & $\begin{array}{c}5 \\
(33.3) \\
\end{array}$ & & 15 \\
\hline $\begin{array}{c}\text { 非手術死亡 } \\
\text { (\% 分布) }\end{array}$ & & $\begin{array}{c}1 \\
(33.3)\end{array}$ & $\begin{array}{c}2 \\
(66.7)\end{array}$ & & 3 \\
\hline $\begin{array}{l}\text { 全患者での } \\
\text { \% 分 布 }\end{array}$ & 56.2 & 25.8 & 16.3 & 1.7 & \\
\hline
\end{tabular}

\begin{tabular}{c|c|c|c|c|c|c|c}
\hline 赤血球 数 & $\geqq 500$ 万 $/ \mathrm{mm}^{3}$ & $\geqq 450$ & $\geqq 400$ & $\geqq 350$ & $\geqq 300$ & $\geqq 300$ & 例 \\
\hline $\begin{array}{c}\text { 手術後死亡 } \\
\text { (\%分布) }\end{array}$ & & $\begin{array}{c}2 \\
(12.5)\end{array}$ & $\begin{array}{c}4 \\
(25.0)\end{array}$ & $\begin{array}{c}4 \\
(25.0)\end{array}$ & $\begin{array}{c}3 \\
(18.8)\end{array}$ & $\begin{array}{c}3 \\
(18.8)\end{array}$ & 16 \\
\hline $\begin{array}{c}\text { 非手術死亡 } \\
(\% \text { 分布) }\end{array}$ & & & $\begin{array}{c}1 \\
(16.7)\end{array}$ & $\begin{array}{c}1 \\
(16.7)\end{array}$ & $\begin{array}{c}1 \\
(16.7)\end{array}$ & $\begin{array}{c}3 \\
(50.0)\end{array}$ & 6 \\
\hline $\begin{array}{c}\text { 全患者での } \\
\% \text { 分 布 }\end{array}$ & 5.2 & 17.1 & 33.4 & 31.2 & 7.8 & 5.4 & \\
\hline
\end{tabular}

献と比較しても悪い成績ではない2).

又, 内視鏡的手術（前立腺切除術）でも，138例中 1 例 $(0.7 \%)$ の死亡例があつた.

これらの死亡例を手術後死亡例と非手術死亡例とに分 讨，更に全老年入院患者を対象群として入院時検査所見 について特に差があるか比較検討してみた。これは術後 の Risk についての予測と治療方針決定に役立てようと せんがためである（表15，表16，表17，表18）.各症例数 が少ないので钽密な比較は適切でないと思われるが，一 般的な傾向としては比較可能と考える.
血圧・ 心電図・赤血球数 - PSP.BUN·BSP 血清 $\mathrm{Na}^{+}$• 血清 $\mathrm{K}^{+}$では, 手術後死亡例は対象群に比して一般に異 常な変化を示す率は高いが，それ程明白な差はない。そ れに対して, 非手術死亡例は対象群に比して明らかな差 がある. 特に, 異常高又心低血圧, 高度の貧血・強度の 心電図学的変化・高カリウム血症を示すものは, 常識的 ながら非手術死亡例に多い。

他方, 血清蛋白量・GOT・GPT などでは, 手術後死 亡例・非手術死亡例・対象群の 3 者間には顕著な差はな W. 
表16 死亡例の入院時所見（II）

\begin{tabular}{c|c|c|c|c}
\hline P S P & $\geqq 25 \%$ & $55>$ & $30>$ & 例数 \\
\hline $\begin{array}{c}\text { 手術後死亡 } \\
\text { (\%分布) }\end{array}$ & $\begin{array}{c}8 \\
(72.7)\end{array}$ & $\begin{array}{c}2 \\
(18.1)\end{array}$ & $\begin{array}{c}1 \\
(9.1)\end{array}$ & 11 \\
\hline $\begin{array}{c}\text { 非手術死亡 } \\
\text { (\%分布) }\end{array}$ & & $\begin{array}{c}2 \\
(33.3)\end{array}$ & $(66.7)$ & 3 \\
\hline $\begin{array}{c}\text { 全患者での } \\
\text { \% 分布 }\end{array}$ & 73.3 & 19.2 & 7.2 & \\
\hline
\end{tabular}

\begin{tabular}{c|c|c|c|c|c}
\hline B U N & $\leqq 20 \mathrm{mg} / \mathrm{dl}$ & $20<$ & $50 \leqq$ & $100 \leqq$ & 例数 \\
\hline $\begin{array}{c}\text { 手術後死亡 } \\
\text { (\%分布) }\end{array}$ & $\begin{array}{c}11 \\
(68.8)\end{array}$ & $\begin{array}{c}2 \\
(12.5)\end{array}$ & $\begin{array}{c}3 \\
(18.8)\end{array}$ & & 16 \\
\hline $\begin{array}{c}\text { 非手術死亡 } \\
\text { (\%分布) }\end{array}$ & $\begin{array}{c}3 \\
(30.0)\end{array}$ & $\begin{array}{c}3 \\
(30.0)\end{array}$ & $\begin{array}{c}(30.0) \\
(10.0)\end{array}$ & 10 \\
\hline $\begin{array}{c}\text { 全患者での } \\
\text { \% 分 布 }\end{array}$ & 63.2 & 31.5 & 5.1 & 0.2 & \\
\hline
\end{tabular}

表17 死亡例の入院時所見（III）

\begin{tabular}{c|c|c|c|c}
\hline T.P. & $\geqq 6.5$ & $\geqq 6.0$ & $6.0>$ & 例数 \\
\hline $\begin{array}{c}\text { 手術後死亡 } \\
(\% \text { 分布 })\end{array}$ & $\begin{array}{c}9 \\
(60.0)\end{array}$ & $\begin{array}{c}5 \\
(33.3)\end{array}$ & $\begin{array}{c}1 \\
(6.7)\end{array}$ & 15 \\
\hline $\begin{array}{c}\text { 非手術死亡 } \\
(\% \text { 分布) }\end{array}$ & $\begin{array}{c}4 \\
(80.0)\end{array}$ & $\begin{array}{c}1 \\
(20.0)\end{array}$ & & 5 \\
\hline $\begin{array}{c}\text { 全患者での } \\
\% \text { 分 布 }\end{array}$ & 80.0 & 15.1 & 4.9 & \\
\hline
\end{tabular}

\begin{tabular}{|c|c|c|c|c|}
\hline GOT & $40 \geqq$ & $>40$ & $>100$ & 例数 \\
\hline $\begin{array}{c}\text { 手術後死亡 } \\
\text { (\%分布) }\end{array}$ & $\begin{array}{c}11 \\
(73.3)\end{array}$ & $\begin{array}{c}3 \\
(20.0)\end{array}$ & $\begin{array}{c}1 \\
(6.7)\end{array}$ & 15 \\
\hline $\begin{array}{c}\text { 非手術死亡 } \\
(\% \text { 分布 })\end{array}$ & $\begin{array}{c}5 \\
(100.0) \\
\end{array}$ & & & 5 \\
\hline $\begin{array}{l}\text { 全患者での } \\
\% \text { 分 布 }\end{array}$ & 92.6 & 6.3 & 1.1 & \\
\hline
\end{tabular}

\begin{tabular}{c|c|c|c|c}
\hline $\mathrm{G} \mathrm{P} \mathrm{T}$ & $35 \geqq$ & $>35$ & $>100$ & 例数 \\
\hline $\begin{array}{c}\text { 手術後死亡 } \\
(\% \text { 分布 })\end{array}$ & $\begin{array}{c}13 \\
(86.7)\end{array}$ & $\begin{array}{c}1 \\
(6.7)\end{array}$ & $\begin{array}{c}1 \\
(6.7)\end{array}$ & 15 \\
\hline $\begin{array}{c}\text { 非手術死亡 } \\
\text { (\%分布) }\end{array}$ & $\begin{array}{c}4 \\
(80.0)\end{array}$ & $\begin{array}{c}1 \\
(20.0)\end{array}$ & & 5 \\
\hline $\begin{array}{c}\text { 全患者での } \\
\text { \% 分 布 }\end{array}$ & 91.4 & 7.8 & 0.8 & \\
\hline
\end{tabular}

\begin{tabular}{c|c|c|c|c}
\hline B S P & $5 \% \geqq$ & $>5$ & $>10$ & 例数 \\
\hline $\begin{array}{c}\text { 手術後死亡 } \\
(\% \text { 分布) }\end{array}$ & $\begin{array}{c}10 \\
(83.3)\end{array}$ & $\begin{array}{c}1 \\
(8.3)\end{array}$ & $\begin{array}{c}1 \\
(8.3)\end{array}$ & 12 \\
\hline $\begin{array}{c}\text { 非手術亡 } \\
\text { (\%分布) }\end{array}$ & $\begin{array}{c}1 \\
(25.0)\end{array}$ & $\begin{array}{c}3 \\
(75.0)\end{array}$ & & 4 \\
\hline $\begin{array}{c}\text { 全患者での } \\
\text { \%分 布 }\end{array}$ & 80.8 & 12.0 & 7.2 & \\
\hline
\end{tabular}

\section{非手術例}

入院するには，手術を前提としているのであるが，精 査の結果手術の必要なしと決定されたもの，薬物・食 餌・照射・ブジー療法のみで手術を施行しないで済んだ
表18 死亡例の入院時所見（IV）

\begin{tabular}{c|c|c|c|c}
\hline \multicolumn{1}{|c|}{$\mathrm{S}^{+} \mathrm{Na}^{+}$} & $\begin{array}{c}>148 \\
\mathrm{mEq} / \mathrm{L}\end{array}$ & 正常 & $136>$ & 例数 \\
\hline $\begin{array}{c}\text { 手術後死亡 } \\
(\% \text { 分布 })\end{array}$ & & $\begin{array}{c}14 \\
(87.5)\end{array}$ & $\begin{array}{c}2 \\
(12.5)\end{array}$ & 16 \\
\hline $\begin{array}{c}\text { 非手術死亡 } \\
(\% \text { 分布 })\end{array}$ & & $\begin{array}{c}5 \\
(83.3)\end{array}$ & $\begin{array}{c}1 \\
(16.7)\end{array}$ & 6 \\
\hline $\begin{array}{c}\text { 全患者での } \\
\% \text { 分 布 }\end{array}$ & 0.2 & 91.3 & 8.5 & \\
\hline
\end{tabular}

\begin{tabular}{c|c|c|c|c}
\hline $\mathrm{S}^{+} \mathrm{K}^{+}$ & $\begin{array}{c}>4.8 \\
\mathrm{mEq} / \mathrm{L}\end{array}$ & 正常 & $3.6>$ & 例数 \\
\hline $\begin{array}{c}\text { 手術後死亡 } \\
(\% \text { 分布 })\end{array}$ & $\begin{array}{c}3 \\
(18.8)\end{array}$ & $\begin{array}{c}12 \\
(75.0)\end{array}$ & $\begin{array}{c}1 \\
(6.2)\end{array}$ & 16 \\
\hline $\begin{array}{c}\text { 非手術死亡 } \\
\text { (\%分布) }\end{array}$ & $\begin{array}{c}3 \\
(50.0)\end{array}$ & $\begin{array}{c}2 \\
(33.3)\end{array}$ & $(16.7)$ & 6 \\
\hline $\begin{array}{c}\text { 全患者での } \\
\text { \% 分 布 }\end{array}$ & 10.6 & 83.1 & 6.3 & \\
\hline
\end{tabular}

\begin{tabular}{c|c|c|c|c}
\hline S-Cl- & mEq/L & 正常 & $98>$ & 例数 \\
\hline $\begin{array}{c}\text { 手術後死亡 } \\
(\% \text { 分布) }\end{array}$ & & 15 & 1 & 16 \\
\hline $\begin{array}{c}\text { 非手術死亡 } \\
(\% \text { 分布) }\end{array}$ & $\begin{array}{c}1 \\
(16.7)\end{array}$ & $\begin{array}{c}(63.8) \\
(66.7)\end{array}$ & $\begin{array}{c}(6.2) \\
(16.7)\end{array}$ & 6 \\
\hline $\begin{array}{c}\text { 全患者での } \\
\text { \% 分 布 }\end{array}$ & 7.1 & 88.6 & 4.3 & \\
\hline
\end{tabular}

\section{ものもある。}

その他，全身状態不良で手術を見合わせたもの，又は いろいろの理由で患者が手術を拒否したものなどがあ る. 患者側の原因により手術を施行しなかつた例は，加 令と共に高率となる傾向が明らかである（表19）.

特に前立腺摘除術と腎摘出術について

前立腺摘除術 :

老年入院患者の $35.1 \%$ は前立腺肥大症の診断の下に手 術的治療の目的で入院し, 泌尿器科では最も多い疾患で ある. それで，特に前立腺摘出術の $2 \cdot 3$ の事項につい て検討してみた。ただ，患者は殆んどが50才以上であ り，壮年者群を対象として比較することは不可能であ る.

術後入院日数をみると，年令区分別にやや差はあるも のの，19日以内に $50 \%$ 前後は退院する. しかし，術後 29 日となつても，いろいろの原因で退院し兄ないもの（術 後30日以上の入院を要するもの）は，明らかに加令と共 に高率となり（表 $20 ， 80$ 才以上では 3 人に 1 人は術後 1 カ月以上の入院が必要之なる。入院日数延長の原因は, 必らずしも単独ではないが，一たび尿瘦を形成すると， 針孔の如き小さなものでも容易に閉鎖せず長期間の入院 を必要とすることがある。

又, 前立腺摘除術では，術中殆んど出血をみないもの 
表19 非手術例とその理由

\begin{tabular}{|c|c|c|c|c|c|c|c|c|}
\hline \multirow{3}{*}{ 年 } & \multicolumn{4}{|c|}{ 患者側 の理由により } & \multirow{3}{*}{$\begin{array}{l}\text { 精査を目 } \\
\text { 的として } \\
\text { 入 院 }\end{array}$} & \multirow{3}{*}{$\begin{array}{l}\text { 薬物食餌 } \\
\text { 照 射 ブ } \\
\text { ジなど }\end{array}$} & \multirow{3}{*}{ 合 計 } & \multirow{3}{*}{$\begin{array}{l}\text { 全患者に } \\
\text { 対する\% }\end{array}$} \\
\hline & \multirow{2}{*}{$\begin{array}{l}\text { 全身状 } \\
\text { 態不良 }\end{array}$} & \multirow{2}{*}{$\begin{array}{l}\text { 手術 } \\
\text { 拒否 }\end{array}$} & \multicolumn{2}{|c|}{ 計 } & & & & \\
\hline & & & 例数 & $\begin{array}{l}\text { 全患者に } \\
\text { 対す\% }\end{array}$ & & & & \\
\hline $60 \sim$ & 1 & & 1 & 0.7 & 9 & 7 & 18 & 11.8 \\
\hline $65 \sim$ & 1 & & 1 & 0.6 & 5 & 5 & 11 & 5.8 \\
\hline $70 \sim$ & 3 & 4 & 7 & 4.4 & 4 & 11 & 22 & 13.9 \\
\hline $75 \sim$ & 1 & 4 & 5 & 6.3 & 3 & 3 & 11 & 13.9 \\
\hline $80 \sim$ & 1 & 2 & 3 & 7.5 & 1 & 4 & 8 & 20.0 \\
\hline 許 & 7 & 10 & 17 & 2.9 & 22 & 30 & 72 & 12.2 \\
\hline $40 \sim 55$ & & 2 & 2 & 0.6 & 32 & 13 & 47 & 14.0 \\
\hline
\end{tabular}

表20 前立腺摘除術後日数と年令 - 術中出血量

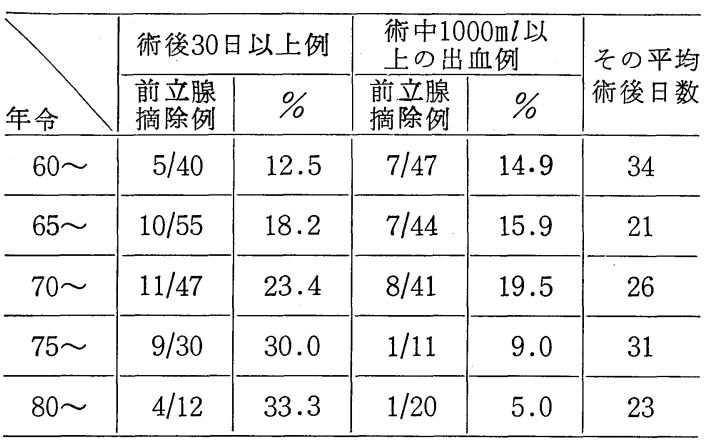

がある反面，かなり大量の出血を来たすこともある，術 中 $1000 \mathrm{ml}$ 以上の出血をみたものをとりあげてみても， 特に加令とは関係ない（表20）。しかし，その平均術後日 数をみると, 我々の手術例では $70 \%$ 以上が 24 日以内に退 院しているので, 大量出血が術後入院日数を延長させる 要因となつていることが判る.

腎摘出術：

特別の場合を除き，腎摘出術は比較的少ない出血量で 容易に行なわれる．しかし，老年者の腎摘出術後，異常 な経過をとるものも時々ある。

腎摘出術後入院日数を老年者群と壮年者群で比較する と（表 $21 ）$,術後 2 週間以内に壮年者の約半数 $(46.6 \%)$ は退院する.他方，老年者では $22.7 \%$ ののが退院する のみである。しかし，19日以内となると壮年者では， $68.8 \%$ ，老年者では77.2\% と逆に多くなり，その後む しろ老年者の方が全般的に早く退院するという結果にな る.

術後合併症をみると（表21）,PSP・BUN 血清一 $\mathrm{Na}^{+}$・ 血清一 $\mathrm{K}^{+}$を腎機能の指標とすれば，腎摘後老年者群は
表21 腎摘術後日数分布

\begin{tabular}{c|c|c|c|c|c|c}
\hline 年令 & 9 日 & $14 \geqq$ & $19 \geqq$ & $24 \geqq$ & $29 \geqq$ & $30<$ \\
\hline $60 \sim$ & $4.5 \%$ & 18.2 & 54.5 & 9.1 & 9.1 & 4.5 \\
\hline $40 \sim 55$ & 4.4 & 42.2 & 22.2 & 17.8 & 6.7 & 6.7 \\
\hline
\end{tabular}

腎摘術後合併症

\begin{tabular}{|c|c|c|c|c|}
\hline & \multicolumn{2}{|c|}{60 才〜で異常例 \% } & \multicolumn{2}{|c|}{$\begin{array}{l}40 \sim 55 \text { 才で } \\
\text { 異常例\% }\end{array}$} \\
\hline & 腎摘後 & 全手術後 & 腎摘後 & 全手術後 \\
\hline P S P & 30.0 & 29.3 & 16.7 & 22.3 \\
\hline B UN & 36.4 & 31.9 & 24.4 & 24.1 \\
\hline $\mathrm{S}-\mathrm{Na}^{+}$ & 22.2 & 14.6 & 9.4 & 11.8 \\
\hline S-K ${ }^{+}$ & 22.2 & 20.2 & 10.0 & 18.2 \\
\hline 消化器出血 & 5.6 & 2.5 & 0 & 1.8 \\
\hline 腸管 麻 痺 & 6.6 & 4.3 & 6.1 & 4.1 \\
\hline
\end{tabular}

壮年者群に比して異常值を示すものが明らかに高率であ る. 老年者群・壮年者群各々に执いて，腎摘出術後と全 手術後例とを比較すれば，老年者群では腎摘後例の方が 異常を示するのが多く，一方，壮年者群では腎摘後例の 方が異常を示するのが少ない．腎摘出術を施行するには 勿論, 術前に他側腎が充分に機能していることを確認し ているのであるが，老年者では腎摘が比較的負担となる が，壮年者では他の一般手術に拈けるよりも負担とはな らないことを示唆するものと解される.

又, 消化器出血も老年者の腎摘出術後には多い.

偶々経験する老年者腎摘出術後異常経過の典型的なも のは, 先ず腸蠕動回復の遅延があり, やがてタール様便 又は血便の排出によつて，それは消化管出血によるもの であることが判る．それに引続いて，比較的尿量・尿比 重が保持されているにかかわらず，BUN・血清 $\mathrm{K}^{+}$值の 
上昇が起こる（腸内容物の停滞・再吸収によつて惹き起 こされるものであろう).これは消化器出血が止まると共 に, 全身的に回復に向 .

このような異常経過が腎摘後の検查所見の平均的異常 という型でよく現われているようにみえる。

$$
\text { まとめ }
$$

1. 60 才以上の老年患者は，全入院患者の約 $1 / 3$ を占 め, 老年者泌尿器科として特別な研究対象とする必要性 を示するのと考えられる。

2. 老年者泌尿器科入院患者の $1 / 3$ 以上は, 前立腺肥大 症の治療を目的として入院する.

3. 全身検査所見で異常を示するのは，加令と共に高 率となる．しかも，術前より術後に異常を呈するものが 多くなる。

4. 手術後死亡例の入院時所見は，死亡せずに退院し
えた例との間に特に差がない，一方，非手術死亡例では 入院時所見に異常を示すものが明らかに多い.

5. 患者側の理由により手術せずに退院するものは， 加令と共に多くなる.

6. 前立腺摘除術後, 異常を呈するのは加令と共に多 くなる。

7. 腎摘出術は, 壮年者では他の一般泌尿器科手術よ りも侵襲が少ないが，老年者では負担が過大となりやす い.

\section{参考文献}

1）疾病・傷害扩よび死因統計分類提要，厚生省大 臣官房統計調查部編。

2) 高安久雄, 西浦常雄, 高崎悦司, 米瀬泰行, 山 本隆司, 田原達雄, 足立卓三, 島野栄一郎 : 日 泌尿会誌，57，279，1966. 